\title{
Deontologia muncii în echipă în contextual actual al muncii la domiciliu ${ }^{1}$
}

\section{Laura MANEA $^{1}{ }^{*}$; Frederico de CARVALHO FIGUEIREDO ${ }^{2}$}

1 Universitatea Transilvania din Brașov, manea@unitbv.ro

2 University Centre Una - MG (Centro Universitario

Una) Brasil. frederico_miarelli@hotmail.com

* Correspondence: manea@unitbv.ro

Citation: Manea, L. \& de Carvalho Figueiredo, F. (2021). Deontologia muncii în echipă în contextul actual al muncii la domiciliu. Revista Etică și Deontologie. 1(1), 104-111, https://doi.org/10.52744/RED.2021.01.13

Publisher's Note: RED stays neutral with regard to jurisdictional claims in published maps and institutional affiliations.

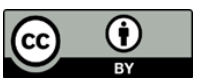

Copyright: (C) 2021 by the authors. Submitted for possible open access publication under the terms and conditions of the Creative Commons Attribution (CC BY) license

(https://creativecommons.org/ licenses/by/4.0/).
Rezumat: Omul ca ființă socială se integrează în colective diferite, în funcție de activitate, și își adaptează comportamentul în funcție de rolul pe care îl ocupă în grupul formal sau informal în care se regăsește. În cazul muncii în echipă, este necesară o anumită coordonare a activităților individuale, stabilirea unor restricții și/sau competențe care să conlucreze la cooperarea membrilor echipei, în condițiile în care în mod individual fiecare membru să fie stimulat spre performanța echipei. Începând cu anul 2020, translatarea activităților angajaților în mediul casnic (munca la domiciliu sau telemuncă) a determinat pe de o parte securizarea personalului din punct de vedere al sănătății, dar distanțarea socială a generat anumite rupturi în cazul activităților derulate în echipe de lucru și preluarea unor activități suplimentare de către unii membri ai echipei, fie din motive tehnice (dotările de acasă nu permit desfășurarea anumitor activități), fie din motive organizatorice. Cercetarea din prezentul studiu urmărește să identifice, în cadrul legal actual al muncii la domiciliu, măsurile prin care angajatorii pot modifica atribuțiile angajaților în cursul derulării raportului de muncă, respectiv cadru legal care permite sau impune angajatorului să opteze pentru munca la domiciliu/telemunca.

Cuvinte cheie: deontologie, munca în echipă, coordonator, munca la domiciliu, telemuncă

\footnotetext{
${ }^{1}$ Articol prezentat în cadrul Conferinței Internaționale Valorile Etice în Societatea Actuală - VESA 2021 (3-5 iunie).
} 


\section{Munca în echipă vs. munca individuală}

Pentru a defini munca în echipă, pornim de la definiția DEX (DEX 2009) a echipei ca fiind un grup de oameni, care sub îndrumarea şi coordonarea unui şef îndeplinesc în acelaşi timp o muncă sau realizează o activitate comună. Astfel, funcționarea unei echipe este condiționată atât de calitățile de coordonare ale șefului, dar în principal persoanele din grup trebuie să aibă trăsături complementare, nu numai din perspectiva muncii, şi să fie animați toți de un scop comun.

Funcționarea în bune condiții a unei echipe și obținerea rezultatelor scontate este dezideratul numeroaselor companii în privința resursei umane, pornind de la premisa de ființă socială a individului, iar prin închegarea unei echipe funcționale şi adaptabile se asigură creșterea productivității companiei (Ueno, 2012), dar totodată şi productivitatea individuală crește (Flores-Szwagrzak, Treibich, 2020). Munca în echipă este o soluție viabilă pentru multe companii în secolul XXI fiind în acord cu filozoful american Henrz David Thoreau : „Să formezi o echipă este doar începutul, să rămâi împreună este progresul, să lucrezi împreună este succesul".

Pe lângă coordonarea echipei prin delegarea responsabilităților şi sarcinilor către fiecare membru, rolul liderului este de a se asigura că fiecare membru conștientizează importanța propriei apartenenței la grup, deoarece rezultatele muncii în echipă se văd atunci când există încredere, colaborare şi comunicare între membrii echipei. Multe organizații se definesc prin promovarea muncii în echipă considerând că munca în echipă aduce plus valoare organizației şi atrage resursă umană calificată.

Este adevărat că există şi profesii în care specificul muncii nu necesită o echipă, un grup, unde sarcinile, nefiind complexe, pot fi îndeplinite de către un singur individ (de exemplu munca unui avocat sau a unui artist), bazându-se exclusiv pe abilitățile şi cunoştințele celui care ocupă acel post. Chiar dacă per ansamblu munca unui individ este complinită ulterior cu rezultatele obținute de un alt coleg din companie, fiecare realizează o muncă individuală.

Munca în echipă crește în timp productivitatea fiecărui membru al grupului prin valorificarea competenței individuale, rolul liderului de a coordona activitatea grupului fiind în fapt un liant între acțiunile membrilor echipei (Tohidi, 2010, p. 1137-1146). Totodată, la munca în echipă, în cazul în care un coleg se află în impas, ceilalți membrii îl pot susține şi complini temporar atribuțiile fără ca rezultatul să fie amânat, ceea ce în cazul muncii individuale, în caz de impas individul îşi poate pierde concentrarea şi poate fi chiar descurajat să continue de teama eșecului.

Indiferent de domeniul de activitate (fie că este vorba de servicii sau de producția de bunuri), în condițiile în care fiecare individ îşi doreşte să performeze în profesia sa şi să evidențieze în fața angajatorului, atât pentru psihicul său, cât şi din motive de securitate financiară a postului, munca în echipă bazată pe o comunicare şi încredere maximă astfel încât membrii se completează şi conlucrează conduce în 
timp, pe lângă rezultatele urmărite de companie, şi la reducerea stresului şi îmbunătățirea vieții personale a membrilor echipei (Hanaysha, 2016, p. 298-306; Berber N. et. al., 2020).

\section{Măsuri legislative privind desfăşurarea activităţii de către companii şi angajaţi în contextul pandemiei de COVID - 19}

Anul 2020 a marcat prin contextul pandemic reorientarea desfăşurării activităților lucrative prin aplicarea principiului distanțării sociale (Raport tehnic 2020) a salariaţilor, fiind activate două forme de muncă care deşi reglementate anterior (munca la domiciliu este reglementată din anul 2003 odată cu adoptarea Codului Muncii - Legea nr. 53/2003 art. 105-107, iar telemunca, ca formă a raportului de muncă, este reglementată din anul 2018 şi în legislația națională prin Legea nr. 81/2018) erau folosite în funcționarea companiilor și instituțiilor publice foarte rar, în cazuri exprese în raport şi de specificul muncii.

Activarea celor două forme de muncă în afara sediului angajatorului a fost determinată în contextul în care distanțarea socială, ca fenomen al anului 2020, este o acțiune care are ca şi scop asumat de autoritățile fiecărui stat reducerea la minimum a contactului dintre persoane, respectiv între angajați, şi prin urmare să reducă riscul infectărilor; măsurile de distanțare socială constau în principal prin contramăsuri nefarmaceutice (CNF) care au ca scop reducerea transmiterii bolii (Anderson R. et. al., 2020) iar pe termen mai lung scopul urmărit fiind reducerea presiunii asupra serviciilor de sănătate prin menținerea sub control a cazurilor pozitive (ECDC 2020).

Organizația Mondială a Sănătății (OMS) a cerut guvernelor statelor membre UE să considere combaterea bolii ca prioritate absolută, în contextul în care în anul 2020 s-au atins cote alarmante ale numărului de infectări și decese (Raport tehnic 2020).

Paradoxal, deși măsura noninvazivă a „distanțării sociale” menționată fără întrerupere de autoritățile medicale şi cele de stat din toate țările se axează pe reducerea până la eliminare a contactului fizic ca metodă de transmitere, reducerea contactului social al indivizilor nu reprezintă un obiectiv al acestor măsuri în timp de criză sanitară.

Deşi s-au aplicat măsuri drastice privind închiderea anumitor activități desfăşurate preponderent în colective mai mari sau mai mici, şi aici menționăm închiderea unităților de învățământ sau închiderea restaurantelor şi incintelor de alimentație publică, succesul măsurilor de distanțare socială depinde de asigurarea contactului social între oameni (cu familia, cu colegii de muncă, cu prietenii) de la distanță, prin intermediul internetului. Astfel, internetul a devenit liantul de comunicare socială în condiții de distanțare socială.

Pe lângă măsurile practice pentru implementarea izolării sociale a indivizilor (dezvoltarea sistemelor de furnizare de servicii - acces la asistență medicală prin telemedicină - și bunuri esențiale - alimente, medicamente prin servicii de curierat în ultimul an s-a dovedit o provocare atât pentru medici cât şi pentru cetățeni menținerea sănătății mintale atât în cazul persoanelor afectate de boală, dar şi a celorlalte (Brooks S. et. al., 2020). Soluția (Willem L., 2020) a constat în menținerea 
legăturilor de familie şi a celor sociale prin sistemele de comunicare on-line, prin rețele sociale şi prin telefon, instrumente folosite de altfel şi în cazul telemuncii sau a muncii de la domiciliu (PHE 2020).

S-a dovedit că măsurile de distanțare socială restrictive au determinat dificultăți financiare nu numai pentru angajatorii din sectoarele direct vizate, dar şi pentru angajați, dificultăți financiare pe termen scurt şi mediu, cea mai gravă fiind închiderea prin faliment a anumitor companii şi pierderea locurilor de muncă pentru angajații din sectoarele cel mai greu încercate (transporturi aeriene, HORECA).

Pentru a fi contracarate implicațiile nefavorabile, guvernele au adoptate norme privind asigurarea unor compensații financiare pentru pierderile suferite atât de către angajatori, cât şi de către salariați prin reducerea timpului de muncă sau încetarea raportului de muncă (Willem L., 2020), sens în care în România au fost adoptate Legea nr. 55/2020 privind unele măsuri pentru prevenirea şi combaterea efectelor pandemiei de COVID-19, Ordonanța de Urgență a Guvernului nr. 30/2020 pentru modificarea şi completarea unor acte normative, precum şi pentru stabilirea unor măsuri în domeniul protecției sociale în contextul situației epidemiologice determinate de răspândirea coronavirusului SARS-cov-2 (OUG 30 reglementează condițiile de acordare a şomajului tehnic în contextul pandemic, dar şi a indemnizațiilor pentru părinții ai căror copii se află acasă pentru activități didactice on-line), Ordonanța de Urgență a Guvernului nr. 70 din 14 mai 2020 privind reglementarea unor măsuri, începând cu data de 15 mai 2020, în contextul situației epidemiologice determinate de răspândirea coronavirusului sars-cov-2, pentru prelungirea unor termene, pentru modificarea şi completarea Legii nr. 227/2015 privind codul fiscal, a Legii educației naţionale nr. 1/2011, precum şi a altor acte normative, respectiv Ordonanța de Urgență a Guvernului nr. 92 din 28 mai 2020 pentru instituirea unor măsuri active de sprijin destinate angajaților şi angajatorilor în contextul situației epidemiologice determinate de răspândirea coronavirusului SARS-CoV-2, precum şi pentru modificarea unor acte normative.

Măsuri similare au fost adoptate în toate statele membre UE şi nu numai, măsuri de susținere de la bugetele statului a companiilor a căror activitate le-a fost suspendată sau închisă pe perioada de vârf a pandemiei, dar şi de acordare a unor ajutoare financiare, inclusiv acoperirea unei părți a veniturilor salariale ale angajaților din companiile astfel afectate. Astfel, în Marea Britanie, unele afaceri din industria hotelieră şi a serviciilor alimentare au primit subvenții, iar pentru IMM-uri s-au acordat împrumuturi de până la 5 milioane de lire, în paralel cu scutirea de plata taxelor pe clădiri pentru afacerile din industria hotelieră; în Germania şi Franța prin acte normative s-au prevăzut acordarea de împrumuturi bancare pentru companiile afectate de COVID 19 şi s-au amânat diferite termene de plată a taxelor şi impozitelor în anul 2020, în Olanda s-au acordat compensaţii de 4000 Euro pentru companiile din industria hotelieră, dar şi din alte industrii afectate semnificativ de pandemie; în Austria, pe lângă măsurile de susținere a companiilor, s-a asigurat prin reglementări interne acordarea de sprijin financiar de până la o treime din costurile salariale angajaților care au rămas acasă pentru a avea grijă de copii (Măsuri guvernamentale 2020). 
Toate aceste măsuri legislative la nivelul statelor membre UE îşi au fundamentul legal şi financiar în Regulamentul (UE) 2020/460 al Parlamentului European şi al Consiliului din 30 martie 2020 de modificare a Regulamentelor (UE) nr. 1.301/2013 și (UE) nr. 508/2014, în ceea ce privește anumite măsuri specifice menite să mobilizeze investiții în sistemele de sănătate ale statelor membre şi în alte sectoare ale economiilor acestora ca reacție la epidemia de COVID-19 - Inițiativa pentru investiții ca reacție la coronavirus.

În contextul distanțării sociale şi al interzicerii desfăşurării anumitor activități, continuarea asigurării activității pentru celelalte companii s-a dovedit a fi posibilă şi plauzibilă prin telemuncă şi prin munca la domiciliu, astfel angajații rămânând la domiciliu sau în afara sediului angajatorilor, distanțați social, dar în contact prin intermediul telefonului şi internetului. Practic, angajații au desfăşurat activități individuale, dar au păstrat contactul cu echipele de muncă şi cu cele din proiecte, munca fiecăruia fiind raportată către membrii grupului prin intermediul internetului şi a sesiunilor de şedințe on-line.

\section{Avantaje şi dezavantaje privind telemunca}

Deși la nivelul Uniunii Europene s-a convenit încă din anul 2000, în cadrul unei reuniuni a Consiliului Europei de la Lisabona ca în contextul evoluției societății informaționale din secolul XXI să se modernizeze prin dezvoltarea unor moduri de lucru flexibile - telemunca - atât pentru angajat, cât şi pentru angajator, care reduce totodată din costurile de producție, dar care să crească totodată competitivitatea şi productivitatea societăților, în România abia în anul 2018 este adoptată norma privind organizarea telemuncii, România optând ca şi Cehia, Ungaria, Polonia şi Slovacia la adoptarea unui act normativ de reglementare a activității de telemuncă (în baza Acordului cadru asupra telemuncii din 2000 state precum Franța, Belgia, Germania şi Italia au implementat telemunca prin contractele colective de muncă la nivel sectorial sau național).

Deşi definită ca fiind o formă de organizare şi prestare a muncii de către salariat în afara sediilor sau punctelor de muncă ale angajatorului, prin folosirea mijloacelor informatice, telemunca se aseamănă cu munca la domiciliu prin faptul că în majoritatea cazurilor cel mai utilizat spațiu este domiciliul angajatului, deşi în cazul telemuncii nu este obligatoriu.

Telemunca are un caracter consensual, nu poate fi impusă de angajator, şi este agreată de comun acord între părțile raportului de muncă prin semnarea unui act adițional la contractul individual de muncă privind regimul de telemuncă.

Conform art. 5 alin. (2) din Legea nr. 81/2018 privind reglementarea activității de telemuncă, contractul individual de munca cu clauza de telemuncă trebuie să cuprindă următoarele:

a) precizarea expresă că salariatul lucrează în regim de telemuncă;

b) perioada şi/sau zilele în care telesalariatul își desfăşoară activitatea la un loc de muncă organizat de angajator, dar în afara spațiilor acestuia;

c) locul/locurile desfăşurării activității de telemuncă, convenite de părți; 
d) programul în cadrul căruia angajatorul este în drept să verifice activitatea telesalariatului şi modalitatea concretă de realizare a controlului;

e) modalitatea de evidențiere a orelor de muncă prestate de telesalariat;

f) responsabilitățile părților convenite în funcție de locul/locurile desfăşurării activității de telemuncă, inclusiv responsabilitățile din domeniul securității şi sănătății în muncă în conformitate cu prevederile art. 7 şi 8 Legea nr. 81/2018;

g) obligația angajatorului de a asigura transportul la şi de la locul desfăşurării activității de telemuncă al materialelor pe care telesalariatul le utilizează în activitatea sa, după caz;

h) obligația angajatorului de a informa telesalariatul cu privire la dispozițiile din reglementările legale, din contractul colectiv de muncă aplicabil şi/sau regulamentul intern, în materia protecției datelor cu caracter personal, precum şi obligația salariatului de a respecta aceste prevederi;

i) măsurile pe care le ia angajatorul pentru ca telesalariatul să nu fie izolat de restul angajaților şi care asigură acestuia posibilitatea de a se întâlni cu colegii în mod regulat.

În privința echipamentelor folosite în muncă de către telesalariat, angajatorul este responsabil cu furnizarea, instalarea şi mentenanța echipamentelor necesare, dar salariatul poate folosi şi propriile echipamente, în timp ce cheltuielile cu comunicarea şi suportul tehnic necesar (abonament internet, parțial cheltuielile de utilități) sunt în sarcina angajatorului.

Munca la domiciliu, în reglementarea Codului Muncii, are în vedere în principal activitățile de producție manuală, şi nu neapărat activități desfăşurate prin mijloace informatice, ceea ce face ca munca în echipă în cazul muncii la domiciliu să nu poată fi organizată. Spre deosebire de aceasta, în cazul telemuncii, prin interconectivitatea internetului angajații pot continua munca în echipă, cu unele limitări fizice, dar comunicarea este practic asigurată obligatoriu (sesiuni de lucru şi şedințe on-line, raportarea electronică a rapoartelor de muncă zilnice).

Şi totuşi, conform statisticilor HR la nivelul anului 2020 pentru companiile vesteuropene (Trello 2020), prin aplicarea noilor metode de lucru la distanță, 39\% dintre angajați consideră că nu se asigură o colaborare suficientă între angajați, în timp ce $67 \%$ dintre respondenți au considerat că prin ședințele on-line se pierde prea mult timp din timpul de muncă care ar putea fi alocat propriilor responsabilități, iar 57\% dintre angajați au declarat că se simt izolați, chiar și în contextul comunicării on-line.

La nivelul României, un studiu realizat pentru anul 2020 în rândul angajatorilor (Productivitatea în telemuncă, 2021) arată că 30\% dintre companii consideră că a crescut productivitatea angajaților în contextul telemuncii, în timp ce 44\% au declarat cp nu au simțit diferențe, fiind un trend constant comparativ cu anul 2019.

Același studiu, arată că pentru anul 2021 se înregistrează o scădere a productivității salariaților din telemuncă, pe fondul epuizării psihice și a lipsei contactului interuman. 


\section{Concluzii}

Deși din perspectivă medicală pe termen lung, distanțarea socială este soluția noninvazivă cea mai facilă și la îndemâna companiilor și a salariaților prin folosirea telemuncii, pe același termen lung se va ajunge la o scădere a productivităţii muncii, în contextul în care izolarea și lipsa contactului fizic interuman va scădea motivația profesională prin lipsa competitivității și pe fondul unei epuizări psihice a salariaților.

Prin folosirea mijloacelor de comunicare on-line se vorbește deja de o oboseală digitală acumulată de salariați, oboseală care este acutizată de lipsa interacțiunii directe, și chiar a apariției unor conflicte la distanță între salariații care nu mai sunt motivați să dea tot ce este mai bun în ei.

Randamentul în telemuncă este diferit de la companie la companie în funcție și de domeniul de activitate, iar diferența de productivitate va fi în favoarea companiilor care vor investi în resurse și beneficii care să vină în sprijinul angajaților proprii, resurse prin care să fie compensată lipsa interacțiunii fizice.

Dacă la începutul pandemiei, companiile se temeau că prin munca la domiciliu și/sau telemuncă activitatea în echipă și activitatea în general a angajaților va fi afectată prin distragerea salariatului de la activitățile profesional fiind în mediul casnic sau în afara locului de muncă, productivitatea în anul 2020 a crescut și datorită entuziasmului de la început al salariaților care, cel puțin în marile orașe, au apreciat confortul domiciliului cu timpul mare pierdut pe drumul înspre și de la serviciu, pauzele de masă sau timpul petrecut cu colegii în discuții informale.

Chiar dacă munca în echipă în condițiile pandemice ale telemuncii nu este foarte mult afectată din punct de vedere organizatoric și funcțional, izolarea și distanțarea socială a slariaților va duce în timp la scăderea productivității muncii pe fondul oboselii angajaților și a scăderii motivației și competitivității acestora.

\section{Referințe}

Anderson R., Heesterbeek H., Klinkenberg D., Hollingswort T., (2020), How will country-based mitigation measures influence the course of the COVID-19 epidemic? Lancet.

Atlassian, (2021 May 18), The importance of teamwork https://www.atlassian.com/blog/ teamwork/the-importance-of-teamwork,

Berber N., Slavic A., Aleksic, (2020), Relationship between Perceived Teamwork Effectiveness and Team Performance in Banking Sector of Serbia, Sustainability 2020, 12, 8753; doi:10.3390/su12208753

Brooks S., Webster R., Smith L., Woodland L., Wessely S., Greenberg N., (2020), The psychological impact of quarantine and how to reduce it: rapid review of the evidence. Lancet, accesat link https://nccdh.ca/resources/entry/the-psychological-impact-of-quarantine-and-how-toreduce-it-rapid-review-of

Codul Muncii (2003) - Legea nr. 53/2003 privind Codul muncii publicat în Monitorul Oficial nr. 72 din 05.02.2003, republicat în Monitorul Oficial nr. 345 din 18.05.2011.

DEX 2009 - Dicţionar Explicativ al Limbii Române, Academia Română, Institutul de Lingvistică „Iorgu Iordan", Editura Univers Enciclopedic.

ECDC 2020 - European Centre for Disease Prevention and Control. Guidelines for the use of nonpharmaceutical measures to delay and mitigate the impact of 2019-nCoV. Stockholm: ECDC. 
Flores-Szwagrzak K., Treibich R., (2020), Teamwork and individual Productivity Management Science, 66 (6) 2523-2544, https://doi.org/10.1287/mnsc.2019.3305

Hanaysha, J., (2016), Examining the effects of employee empowerment, teamwork, and employee training on organizational commitment, Procedia Soc. Behav. Sci. 2016.

Legea 81 - Legea nr. 81/2018 privind reglemetnarea activității de telemuncă, publicată în Monitorul Oficial nr. 296 din 02.04.2018.

Legea 55 - Legea nr. 55/2020 privind unele măsuri pentru prevenirea şi combaterea efectelor pandemiei de COVID-19, publicată în Monitorul Oficial nr. 396/15.05.2020.

Măsuri guvernamentale 2020 - Măsuri guvernamentale pentru a sprijini companiile în timpul pandemiei de Coronavirus (COVID 19), accesată link https://www.bierensgroup.com/ro/ article/masuri-guvernamentale-companiile-pandemie-coronavirus/

OUG 30 - Ordonanța de urgență a Guvernului nr. 30/2020 pentru modificarea și completarea unor acte normative, precum şi pentru stabilirea unor măsuri în domeniul protecției sociale în contextul situației epidemiologice determinate de răspândirea coronavirusului SARS-CoV-2, publicată în Monitorul Oficial nr. 231 din 21.03.2020.

OUG 70 - Ordonanța de Urgență a Guvernului nr. 70 din 14 mai 2020 privind reglementarea unor măsuri, începând cu data de 15 mai 2020, în contextul situației epidemiologice determinate de răspândirea coronavirusului sars-cov-2, pentru prelungirea unor termene, pentru modificarea și completarea Legii nr. 227/2015 privind codul fiscal, a Legii educației naționale nr. 1/2011, precum și a altor acte normative, publicată în Monitorul Oficial nr. 394 din 14.05.2020.

OUG 92 - Ordonanța de Urgență a Guvernului nr. 92 din 28 mai 2020 pentru instituirea unor măsuri active de sprijin destinate angajaților şi angajatorilor în contextul situației epidemiologice determinate de răspândirea coronavirusului SARS-CoV-2, precum şi pentru modificarea unor acte normative, publicată în Monitorul Oficial nr. 459 din 29.05.2020.

PHE (2020), Public Health England. Guidance on social distancing for everyone in the UK - 20 March 2020. London: accesat link: https://www.gov.uk/government/publications/ covid-19-guidance-on-social-distancing-and-for-vulnerablepeople/guidance-on-socialdistancing-for-everyone-in-the-uk-and-protecting-older-people-and-vulnerableadults

Productivitatea în telemuncă (2021, Aprilie). Cornea A., Ziarul financiar on-line accesat link https://www.zf.ro/zf-supliment-telemunca/productivitatea-in-telemunca-ii-facemunca-de-la-distanta-mai-20056843

Raport tehnic (2020, Martie) ECDC - Considerații referitoare la măsurile de distanțare socială ca răspuns la COVID19, accesat link https://www.ecdc.europa.eu/sites/default/files/ documents/Guide-for-social-distancing-measures_RO.pdf

Regulamentul UE nr. 1.301/2013 şi (UE) nr. 508/2014 în ceea ce privește anumite măsuri specifice menite să mobilizeze investiții în sistemele de sănătate ale statelor membre şi în alte sectoare ale economiilor acestora ca reacție la epidemia de COVID -19 - Inițiativa pentru investiții ca reacție la coronavirus, publicat în OJ L 99, 31.3.2020, p. 5-8, accesat link https://eur-lex.europa.eu/legal-content/RO/TXT/?uri=celex:32020R0460

https://eur-lex.europa.eu/legal-content/RO/TXT/?uri=celex:32020R0460

Tohidi A., (2010), Teamwork productivity \& effectiveness in an organiyation base on rewards, leadership, training, goals, wage, size, motivation, measurement and information technology. In Procedia Computer Science, Vol. 3.

Trello, 2020 - Strike the Balance between Individual and Team Contributions, by Boogaard K., accesat link https://blog.trello.com/individual-contributions-vs-team-collaborations

Ueno A., (2012), The Impact of Teamwork on Productivity: New Evidence for the Service Sector. In the 2012 Academy of World Business, Marketing \& Management Development Conference, accesat la https://www.researchgate.net/publication/283302485_The_ Impact_of_Teamwork_on_Productivity_New_Evidence_for_the_Service_Sector

Willem L., Hoang T., Funk S., Coletti P., Beutels P., Hens N., (2020), An online tool leveraging a social contact data sharing initiative to assess mitigation strategies for COVID-19. MedRxiv, accesat link https://www.medrxiv.org/content/10.1101/2020.03.03.20030627v1.full 